\title{
KRT72 Gene Mutation
}

National Cancer Institute

\section{Source}

National Cancer Institute. KRT72 Gene Mutation. NCI Thesaurus. Code C150653.

A change in the nucleotide sequence of the KRT72 gene. 